\title{
Waste Biomass as Alternative Bio-Fuel- Co-Firing versus Direct Combustion
}

\author{
Gavrilă Trif-Tordai and Ioana Ionel \\ "Politehnica" University of Timisoara \\ Romania
}

\section{Introduction}

Efficient and environmental friendly energy production technologies are strongly requested in the developing countries due to rapid economic growth. Especially for the southeastern countries, biomass resources are abundant. Therefore, the developing countries need the utilization technologies of biomass to produce energy. This study contributes to constructing ecological energy production systems in the developing countries due to enhanced possibilities of biomass utilization. Use of biomass, which is considered to produce no net $\mathrm{CO}_{2}$ emissions in its life cycle, can reduce the effective $\mathrm{CO}_{2}$ emissions of a coal-fired power generation system, when co-fired with coal, but may also reduce system efficiency. In this context of fossil fuels depletion and the desire to reduce greenhouse gases emissions (GHG), the use of biomass in energy purposes needs more attention, in respect to practical applications.

As it is known, the term biomass means total amount of living matter that is included in all living creatures on our planet: plants, animals, and micro and macro organisms. As origin, biomass is a storage form for solar energy.

In general, two main originated groups of biomass sources exist: vegetal and animal. Vegetal biomass often called phytomass, holds the lead in capturing solar energy through the process of photosynthesis and provides almost exclusively the energy required for all other forms of life from planet, including animal biomass.

Obviously phytomass is used mainly to feed animals and people; another important part is raw material for industry and only scrap (waste) from these activities is capitalized in energy purpose. The main possible sources of biomass, convertible into fuel, are listed in Table 1.

Co-firing is regarded as a great opportunity for replacing coal used for power generation with renewable fuels with low costs and a direct repercussion in the decrease of greenhouse gas emissions. During the last decades researches has provided very diverse solutions for co-firing biomass in coal power stations with a limited impact in efficiency, operation and lifespan (Ionel et all., 2009).

In fact, the difficulties in harvesting (collecting), transport, primary processing and eventual phytomass storage before conversion to energy - are often some of the hardest problems to solve because of the large territorial dispersion and quite low energy density (Ionel et all., 2007). The data presented in Table 2 shows that compared with fuel oil, the amount of 
biomass which through combustion releases the same amount of heat is about 10-17 times higher for sawdust and about 18-23 times higher for straw bales.

\begin{tabular}{|l|l|}
\hline Wastes & Residues \\
\hline 1. Ranch: & 1. From agricultural and vegetable \\
- manure. & production: \\
2. Food industry: & - straw (straw cereals), \\
- sugar factory (grain, molasses). & - cobs and corn ear, \\
3. Milk industry. & - spindle (potatoes, tomatoes, pepper), \\
4. Wood industry: & - sugar beet. \\
- sawdust, wood chips, small pieces of & 2. From forestry: \\
wood & - bark, kindling, rind. \\
- wood from demolished buildings. & 3. From wine and fruit growing docks: sprout, \\
& branch. \\
\hline
\end{tabular}

Table 1. Possible sources of biomass convertible into fuel

\begin{tabular}{|l|c|c|c|c|}
\hline \multicolumn{1}{|c|}{ Phytomass } & $\begin{array}{c}\text { Net } \\
\text { calorific } \\
\text { value } \\
\mathrm{H}_{\mathrm{i}}[\mathrm{MJ} / \mathrm{kg}]\end{array}$ & $\begin{array}{c}\text { Density } \\
\sigma\left[\mathrm{kg} / \mathrm{m}^{3}\right]\end{array}$ & $\begin{array}{c}\text { Energy } \\
\text { density } \\
\sigma_{\mathrm{E}}\left[\mathrm{MJ} / \mathrm{m}^{3}\right]\end{array}$ & $\begin{array}{c}\text { Energy density } \\
\text { relative } \\
\text { to fuel oil }\left(\sigma_{\mathrm{E}}\right)_{\mathrm{R}}\end{array}$ \\
\hline Fuel oil & 39.39 & 854 & 33.64 & 1.00 \\
\hline Pit coal & 20.05 & 830 & 16.64 & 2.02 \\
\hline Brown coal & 9.85 & 720 & 7.09 & 4.74 \\
\hline Small pieces of wood & $18.5-18.8$ & $297-380$ & $5.55-7.05$ & $4.77-6.06$ \\
\hline Sawdust & $17.8-18.0$ & $110-170$ & $1.96-3.06$ & $10.99-17.16$ \\
\hline Wood chips & $18.2-18.6$ & $90-153$ & $1.64-2.85$ & $11.80-20.51$ \\
\hline Bark & $18.0-19.2$ & $205-320$ & $3.69-6.10$ & $5.51-9.12$ \\
\hline Straw bale & $17.1-17.5$ & $85-104$ & $1.45-1.82$ & $18.48-23.20$ \\
\hline Hemp stalk & $16.9-17.1$ & $140-170$ & $2.37-2.91$ & $11.56-14.19$ \\
\hline Cereal grains & $16.9-17.0$ & $730-760$ & $12.34-12.92$ & $2.60-2.73$ \\
\hline Wood pellets & 18.0 & 650 & 11.7 & 2.875 \\
\hline
\end{tabular}

Table 2. Energy characteristics for biomass

Romania possesses a large potential of biomass, and is expected to make considerable efforts to make benefit of the European knowledge and dissemination of recent technologies in order to use the potential energy accumulated by the biomass. As Figure 1 indicates, in addition to existing large renewable energy sources (RES) assured especially by the hydraulic energy system, that is quite developed, the next future necessitates development in areas such as biomass, wind and solar energy exploitation (Hansson et all., 2009). 


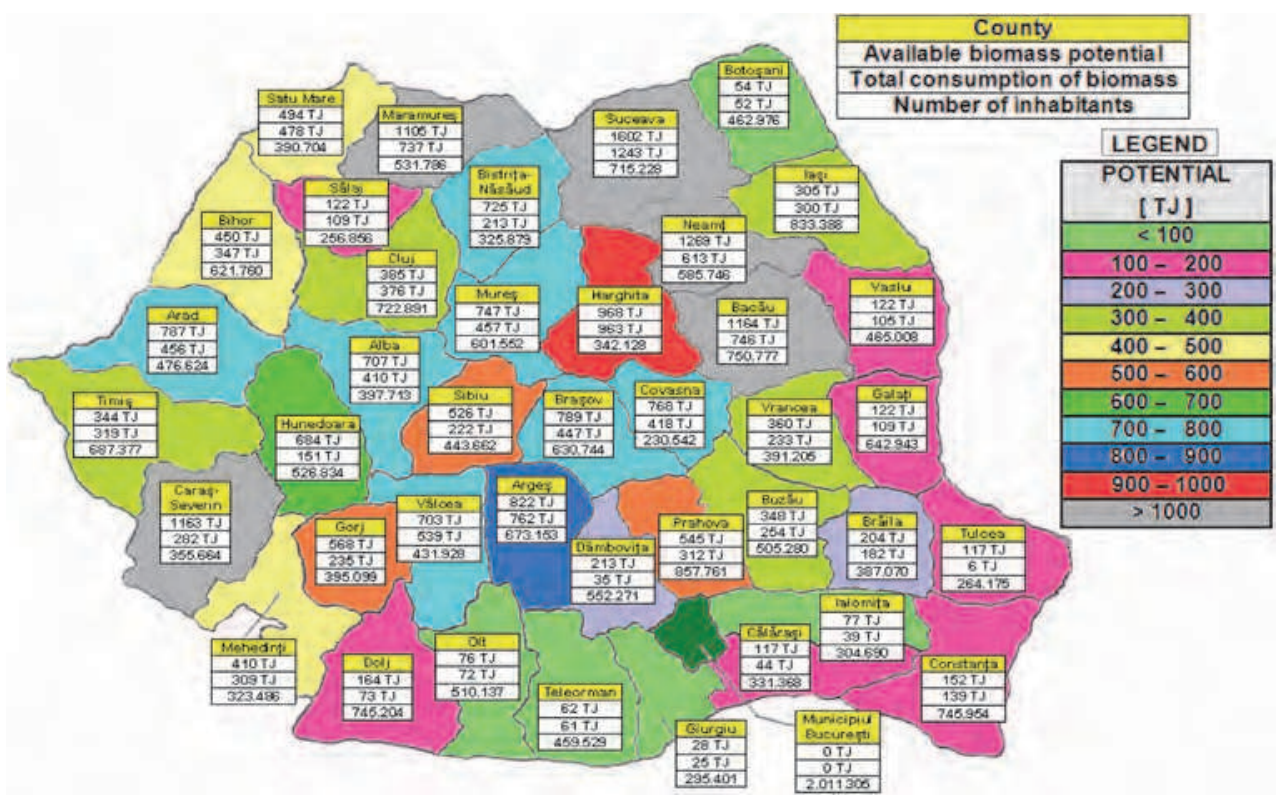

Fig. 1. Biomass distribution in Romania (T,ânțăreanu, 2009)

\section{Current techniques for energy conversion}

In Table 3 are mentioned the main energy conversion techniques for the biomass. Currently, the world's attention is directed particularly to the possibilities of producing alcohol, vegetable oil and biogas, in a word, bio-fuels used mainly in internal combustion engines (Ghergheleş, 2007).

\begin{tabular}{|l|l|}
\hline Process & Product \\
\hline $\begin{array}{l}\text { a) Thermal } \\
\text { - direct combustion }\end{array}$ & Thermal energy, ash and flue gases $\left(\mathrm{CO}_{2}, \mathrm{H}_{2} \mathrm{O}, \mathrm{N}_{2}\right)$ \\
- pyrolysis & Charcoal, oil, fuel gases $\left(\mathrm{CO}, \mathrm{CH}_{4}, \mathrm{H}_{2}\right)$ \\
- gasification & Fuel gases $\left(\mathrm{CO}, \mathrm{H}_{2}\right)$ and inert gases $\left(\mathrm{N}_{2}, \mathrm{CO}_{2}\right)$ \\
- gasification+catalytic synthesis & Methanol, hydrocarbons \\
\hline $\begin{array}{l}\text { b) Biological } \\
\text { - fermentation with yeasts } \\
\text { - anaerobic decomposition }\end{array}$ & ${\text { Ethanol, } \mathrm{CO}_{2}}^{\mathrm{CH}_{4}, \mathrm{CO}_{2}}$ \\
\hline $\begin{array}{l}\text { c) Mechanical } \\
\text { - extraction by pressing }\end{array}$ & Oil \\
\hline $\begin{array}{l}\text { d) Chemical } \\
\text { - extraction with solvents }\end{array}$ & Oil \\
\hline
\end{tabular}

Table 3. Techniques for converting biomass

Direct combustion of biomass for heating, hot water production and steam generation is performed in specific facilities, provided with stoves, hot water boilers or steam generators. 
Conversion efficiency is around $30 \%$ for stoves, $65 \%$ for hot water boilers and can increase to $90 \%$ for modern facilities with intensified combustion in circulating fluidized bed.

Pyrolysis is a complex process of destructive distillation of phytomass without air, which occurs at temperatures between 200 and $1100{ }^{\circ} \mathrm{C}$. Depending on the used technique, in general, the resulted products are: $35 \%$ charcoal, $35 \%$ liquid distillate and $30 \%$ fuel gases $\left(\mathrm{CO}, \mathrm{CH}_{4}\right.$ and $\left.\mathrm{H}_{2}\right)$. Charcoal is used as activated carbon for gas purification, liquid distillate can be used directly to produce fuel or raw chemical materials; combustible gases can be burned in the furnace of power plants.

Gasification allows the thermal conversion of biomass in a combustible gas mixture. Mainly, two gasification techniques are known:

- Gasification in air flow, which leads to the formation of a gas mixture $\left(\mathrm{CO}, \mathrm{H}_{2}, \mathrm{CH}_{4}\right.$, $\left.\mathrm{N}_{2}, \mathrm{CO}_{2}\right)$, with high nitrogen content $(42-45 \%)$ and lower energy value $\left(4-8 \mathrm{MJ} / \mathrm{m}^{3} \mathrm{~N}\right)$ used as fuel in small combustion plants;

- Gasification in oxygen flow, which leads to the formation of synthesis gas with a much higher energy value $\left(10-20 \mathrm{MJ} / \mathrm{m}^{3} \mathrm{~N}\right)$. This can be burned to produce heat used for different purposes or can be used to produce methanol for internal combustion engines. Direct liquefaction is used to convert biomass into liquid bio-fuels through catalytic hydrogenation of wood. The result is a mixture of liquids, used as fuel or as raw material for chemisation. Direct liquefaction can be applied to cellulosic or lingo-cellulosic wastes. Carbon monoxide and water vapor are used for hydrogenation of biomass in the presence of a catalyst (sodium carbonate) resulting oils and gases with high methane content.

Anaerobic decomposition (fermentation) is a process for conversion of various organic substances under the action of enzymes produced by microorganisms in the absence of oxygen in the air. Anaerobic fermentation processes take place in three stages - liquefaction, formation of acids and methane production - as a result of simultaneous action of three communities of microorganisms that appear and develop during those stages, resulting in biogas and sludge formation. Sludge can be used as organic fertilizer for plants.

Specific biogas production and composition vary according to the nature and composition of raw materials, decomposition degree of organic substances, fermentation temperature, fermentation period of organic material and other factors. The biogas produced in this way usually contains 50-65\% $\mathrm{CH}_{4}, 25-45 \% \mathrm{CO}_{2}$ and in very small proportion $\mathrm{CO}, \mathrm{H}_{2}, \mathrm{~N}_{2}, \mathrm{O}_{2}$ and $\mathrm{H}_{2} \mathrm{~S}$. The biogas with $60 \% \mathrm{CH}_{4}$ and $40 \% \mathrm{CO}_{2}$ has the net calorific value $\mathrm{H}_{\mathrm{i}}=21.5 \mathrm{MJ} / \mathrm{m}^{3} \mathrm{~N}$ and ignites at a temperature of $600-750{ }^{\circ} \mathrm{C}$ if mixed with air within $6-12 \%$.

Remarkable progresses in the use of waste biomass for biogas production have been reported in many countries (India, China, USA etc.). In Romania, concerns in this direction date over 30 years, but without a coordinated approach in results implementation from scientific researches.

\section{Co-firing pilot in bubbling fluidized bed}

Co-firing of biomass and coal has been demonstrated successfully in several coal-fired boilers in Europe and the United States. The results have been promising - boiler efficiencies have not suffered considerably. However, when converting existing coal-fired boiler for biomass/coal co-firing, the save share of biomass depends on biomass and coal properties as well as boiler design, and must be determined case by case.

A fluidized bed is a bed of solid particles suspended or fluidized by forcing air through the bed. The high heat transfer and mixing encourage complete combustion. When the air 
velocity is increased above the minimum fluidization velocity, air flows through the bed as bubbles. This type of bed is called bubbling fluidized bed (BFB). When the air velocity is increased, the particles are carried higher up in the reactor. With a circulating fluidized bed (CFB) it is no longer possible to distinguish between the bed and freeboard area. A large fraction of the particles rise up from the bed and are circulated with the help of a cyclone back to the bed. The circulating bed material can be used for temperature control in the boiler. Fluidization velocity of a bubbling fluidized bed boiler is typically 1-3.5 m/s, whereas in a circulating fluidized bed boiler it is 3-6 m/s (European Commission, 2003).

Fluidized bed boilers can be designed to burn almost any solid, semi-solid or liquid fuel as long as the calorific value is sufficient to heat the fuel, drive off the moisture and preheat the combustion air. They achieve high fuel-to-steam efficiency, typically over $90 \%$, even with challenging, low-grade fuels. Because of the high amount of hot circulating bed material, it is possible to burn moist, heterogeneous fuels with low calorific value. With high moisture content fuels, a support fuel can be used. More than $90 \%$ of the bed is sand or ash and the rest is fuel.

At the moment, fluidized bed combustors are the best combustion systems thanks to their ability to burn a wide assortment of fuels and still keep emissions low. The choice between BFB and CFB technology has been largely linked to the choice of fuels. As a simpler and cheaper technology, BFB has been favoured in plants fuelled exclusively with biomass or similar low-grade fuels containing highly volatile substances. The new enhanced CFB designs can be a competitive alternative even in smaller biomass fired plants. Fluidized bed combustion systems are suitable for large-scale applications exceeding $30 \mathrm{MW}_{\text {th }}$ in size (European Commission, 2005).

The co-firing facility, presented in Figure 2, comprises several main parts and is based on original design (Romanian patent no. 121362, 2007). The main characteristics of the co-firing facility are presented in Table 4.

The bubbling bed combustion furnace has a parallelepiped shape $(1 \times 0.5 \times 1 \mathrm{~m})$ and it's made from $3 \mathrm{~mm}$ heat-resisting steel with truncated pyramid base. At the bottom is mounted the air distributor, divided in compartments for injection of the fluidization air and main combustion air through 37 nozzles, and an appropriate air feeding system including a Cole-Parmer regenerative blower and all necessary adaptors. The furnace is equipped with two fuel bunkers each having a helical conveyer coupled to variable speed motors which allow flow adjustments. For start up, on one side of the furnace is connected a Riello gas burner working with natural gas or biogas. Exterior insulation applied to furnace, ash cooler and convective case is made with several layers of ceramic fiber and one layer of mineral wool. For safety, the furnace is fitted with copper explosion valves.

The heat transfer subassembly components are mainly formed by the convective case and one heat exchanger. The convective case has a parallelepiped shape and it's made from W4841 heat-resisting steel. The case is split in two by a stainless steel vertical wall, attached to the top. The heat exchanger is made from 8 cold-drawn steel pipes, 4 in each side, connected to inlet and outlet manifolds. The ash is collected at the bottom in a pyramidal bunker.

The flue gases de-dusting system components are formed by a cyclone dust separatorcylindrical body mounted in vertical position with a tangential upside connection, flow measuring sockets, powder/flue gas sampling, thermocouples and manometers.

The flue gases cleaning subassembly is formed by a scrubbing tower, neutralization reactor and the demister. The scrubbing tower and the neutralization reactor for gaseous pollutants 
have a cylindrical body mounted in vertical position with a cone shaped basis. The parallelepiped shaped demister is equipped with vertical baffles for retention of excessive humidity in cleaned flue gases. Both scrubber and reactor are equipped with the necessary equipments for hydraulic circuit of washing liquids and a $100 \mathrm{~mm}$ layer of Rasching rings to increase the residence time and to provide a large surface area for interaction between washing liquid and flue gases.

In order to control the processes, the experimental facility is equipped with measuring instruments, devices for temperatures, pressures, water and gas flows and visors. All facility components are mounted on a steel frame with overall dimensions: $\mathrm{L}=6 \mathrm{~m}, \mathrm{~W}=1.3 \mathrm{~m}$ and $\mathrm{H}=2.6 \mathrm{~m}$.

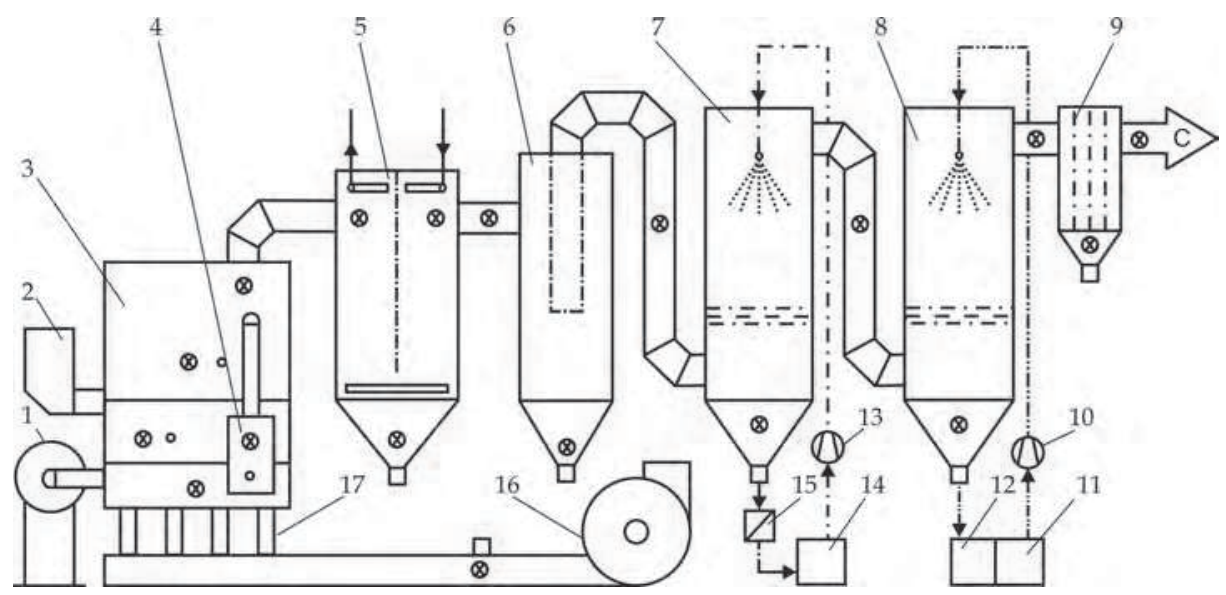

1-Start-up burner, 2-Fuel bunkers, 3-Bubling fluidized bed furnace (BFB), 4-Ash cooler, 5-Convective case, 6-Dust separator-cyclone, 7-Scrubbing tower, 8-Neutralization reactor, 9-Demister, 10, 13-Reagents circulation pumps, 11, 12, 14-Containers, 15-Filter, 16-Air feeding system, 17-Air distributor, C-Chimney

Fig. 2. Design of the co-firing facility in fluidized bed (Trif-Tordai, 2008)

\begin{tabular}{|l|c|}
\hline \multicolumn{1}{|c|}{ Characteristics } & Value \\
\hline Thermal energy output & $45-90 \mathrm{~kW}_{\text {th }}$ \\
\hline Electrical power consumption & $2-4 \mathrm{kWh}_{\mathrm{el}}$ \\
\hline Water flow (in heat transfer system) & $2-4 \mathrm{~m}^{3} / \mathrm{h}$ \\
\hline Combustion / fluidization air flow & max. $270 \mathrm{~m}^{3} / \mathrm{h}$ \\
\hline Compressed air flow (for washing pumps) & $0.5-1 \mathrm{~m}^{3} / \mathrm{h}$ \\
\hline Coal mass flow & $25-50 \mathrm{~kg} / \mathrm{h}$ \\
\hline Biomass mass flow & $15-30 \mathrm{~kg} / \mathrm{h}$ \\
\hline Washing liquid flow & $0.2-0.6 \mathrm{~m}^{3} / \mathrm{h}$ \\
\hline Resulted ash mass flow & $10-20 \mathrm{~kg} / \mathrm{h}$ \\
\hline
\end{tabular}

Table 4. Main characteristics of the co-firing facility 


\section{Co-firing fuels and potential emissions}

According to the promising biomass potential available for heat and electricity production, based in Romania on the stock of wood and agriculture, researches have been developed, in order to utilize different qualities of available biomass as second fuel in the co-firing process, characterized by low price compared to coal, for a comparative energy offer (Romanian Ministry of Environment and Forests, 2007).

Figure 3 presents four different fuels used in co-firing facility: waste biomass (corncob "Cc", respectively sawdust "Sd") and coal (pit coal "Pc" from the Jiu Valley basin and lignite "L" from Oltenia basin).

After drying and milling, the secondary fuels were mixed externally with the basic fuel, before being fed to the combustion system. All other methods - as separate feeding determined lack of stability and non-homogenous temperature levels, and the risks of thermal strength were raised, and were abandoned.

Table 5 gives the elementary analysis for in use coal and biomass qualities. Notable is the $S$ content, as well the lower humidity of the pit coal in comparison to the used biomass. Also the $\mathrm{N}$ content in biomass is sensible reduced in comparison to that of the pit coal.
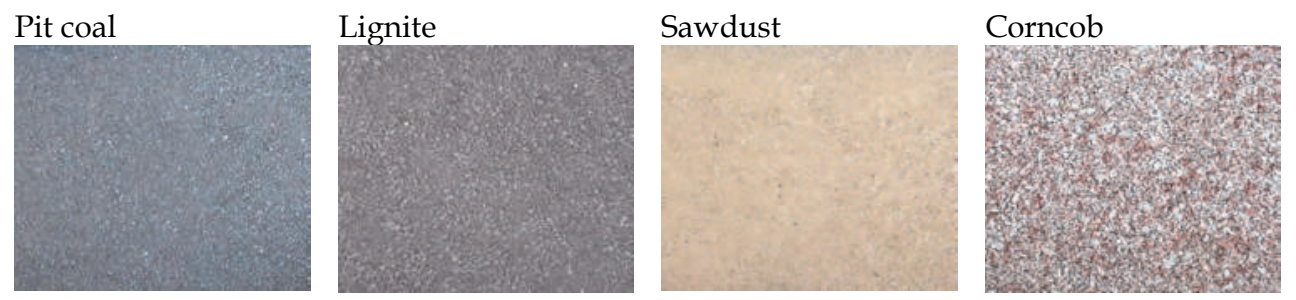

Fig. 3. Types of coal and biomass used as fuels for co-firing facility

\begin{tabular}{|c|c|c|c|c|c|c|}
\hline Characteristics & Symbol & $\begin{array}{c}\text { IS } \\
\text { unit }\end{array}$ & $\begin{array}{c}\text { Pit coal } \\
\text { "Pc" }\end{array}$ & $\begin{array}{c}\text { Lignite } \\
\text { "L" }\end{array}$ & $\begin{array}{c}\text { Sawdust } \\
\text { "Sd" }\end{array}$ & $\begin{array}{c}\text { Corncob } \\
\text { "Cc" }\end{array}$ \\
\hline Carbon & $\mathrm{C}^{\mathrm{i}}$ & $\%$ & 58.84 & 23.48 & 35.97 & 43.62 \\
\hline Hydrogen & $\mathrm{H}^{\mathrm{i}}$ & $\%$ & 2.24 & 2.24 & 4.60 & 4.64 \\
\hline Oxygen & $\mathrm{O}^{\mathrm{i}}$ & $\%$ & 10.64 & 11.35 & 28.96 & 21.11 \\
\hline Nitrogen & $\mathrm{N}^{\mathrm{i}}$ & $\%$ & 2.26 & 0.59 & 0.35 & 0.44 \\
\hline Sulfur & $\mathrm{S}^{\mathrm{i}}$ & $\%$ & 1.80 & 0.85 & 0.01 & 0.01 \\
\hline Humidity & $\mathrm{W}_{\mathrm{t}}^{\mathrm{i}}$ & $\%$ & 8.00 & 43.29 & 30.00 & 29.87 \\
\hline Ash & $\mathrm{A}^{\mathrm{i}}$ & $\%$ & 16.22 & 18.20 & 0.12 & 0.31 \\
\hline $\mathrm{NHV}$ & $\mathrm{H}_{\mathrm{i}}^{\mathrm{i}}$ & $\mathrm{kJ} / \mathrm{kg}$ & 21089 & 8035 & 13023 & 16516 \\
\hline
\end{tabular}

Table 5. Elementary proximate analysis for the used fuels, in reference to humid state

Figure 4 presents eight different mixtures, between waste biomass and coal, used as fuels in co-firing facility. The visual analysis indicates disperse homogeneous, quite raw aspect and various grinding. 


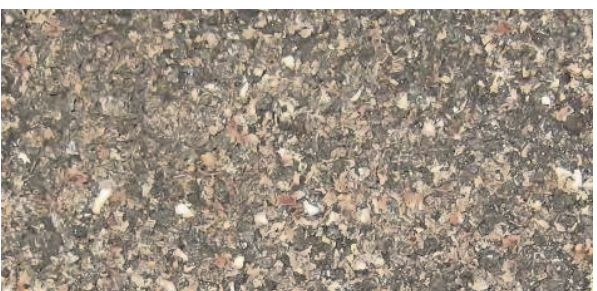

a) $15 \%$ by mass corncob with $85 \%$ pit coal mixture

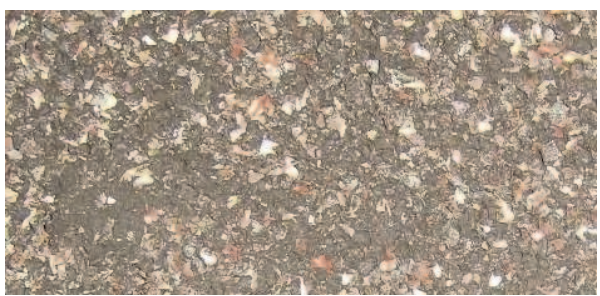

c) $15 \%$ by mass corncob with $85 \%$ lignite mixture

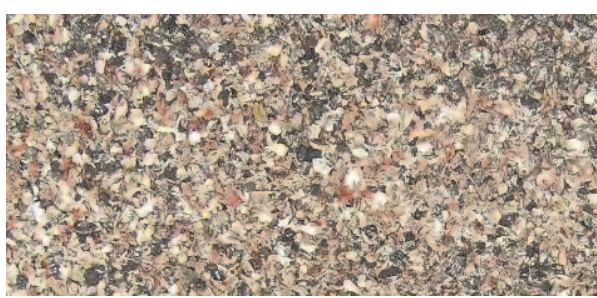

e) $30 \%$ by mass corncob with $70 \%$ pit coal mixture

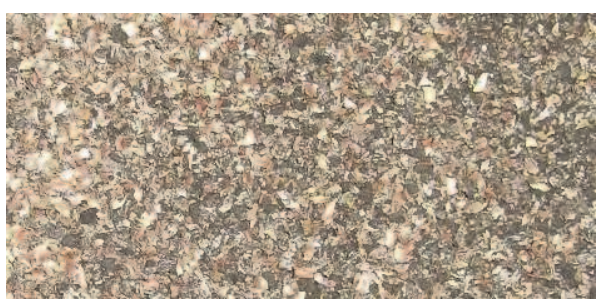

g) $30 \%$ by mass corncob with $70 \%$ lignite mixture

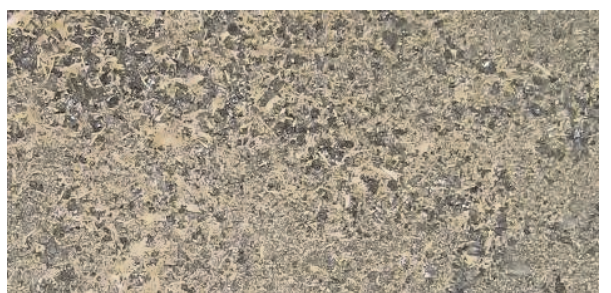

b) $15 \%$ by mass sawdust with $85 \%$ pit coal mixture

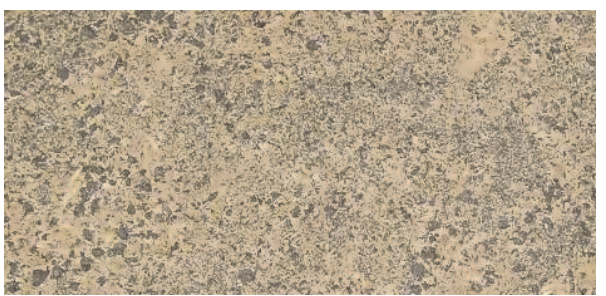

d) $15 \%$ by mass sawdust with $85 \%$ lignite mixture

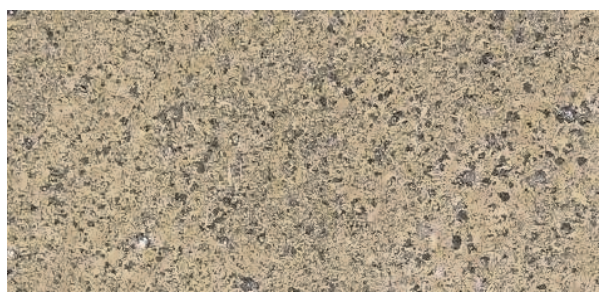

f) $30 \%$ by mass sawdust with $70 \%$ pit coal mixture

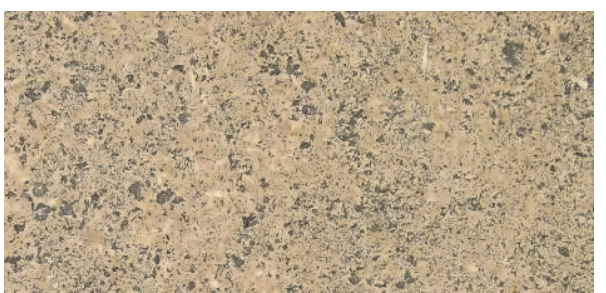

h) $30 \%$ by mass sawdust with $70 \%$ lignite mixture

Fig. 4. Eight different mixtures, between biomass and coal, used as fuels in co-firing facility

Based on the chemical composition of biomass compared to other solid fuels in a Van Krevelen diagram, the biomass fuels are high in the $\mathrm{O} / \mathrm{C}$ - and $\mathrm{H} / \mathrm{C}$ - ratios compared to peat and coals (Figure 5). These high ratios are responsible for the biomass fuels being more volatile than coals and peat, fact that determines a better stability in the ignition process. The $\mathrm{O} / \mathrm{C}$ - ratios is responsible for the fuels lower heating values. 
Depending on the fuel composition, the design of the combustion chamber and the operation technology of the system, biomass combustion can lead to emissions of $\mathrm{CO}, \mathrm{HC}$, (VOC, UHC), $\mathrm{PAH}$, tar, soot, particles, $\mathrm{NOx}, \mathrm{N}_{2} \mathrm{O}, \mathrm{HCl}, \mathrm{SO}_{2}$, salts, $\mathrm{PCDD} / \mathrm{F}$ and heavy metals ( $\mathrm{Pb}, \mathrm{Zn}, \mathrm{Cd}$ and others).

Two main groups of pollutants from the combustion of the fuel combination (coal with waste biomass) are expected: unburnt pollutants such as $\mathrm{CO}, \mathrm{HC}, \mathrm{PAH}$ and soot, and oxidized pollutants such as $\mathrm{NOx}, \mathrm{SO}_{2}$ and $\mathrm{CO}_{2}$.

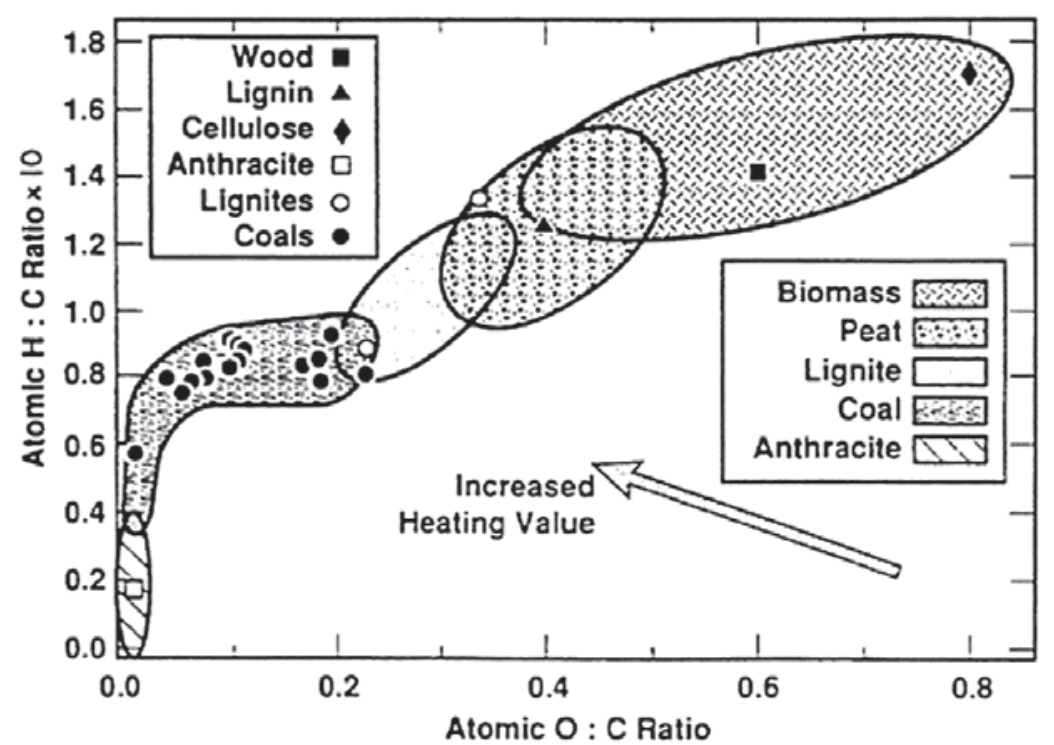

Fig. 5. Van Krevelen diagram for various solid fuels (Van Loo \& Koppejan, 2007)

Further, additional pollutants can be emitted if biomass contains $\mathrm{Cl}$, metals etc.

The emissions from biomass combustion are distinguished as:

- Emissions which are mainly influenced by the quality of the combustion process and operation of the convective system (unburnt pollutants which can be avoided by complete combustion: $\mathrm{CO}, \mathrm{HC}, \mathrm{PAH}$ etc.).

- Emissions which mainly originate from the fuel properties (emissions which are formed from elements found in the waste and are not to the same extend dependent on the combustion process: $\mathrm{NOx}$ from $\mathrm{N}, \mathrm{HCl}$ from $\mathrm{Cl}$ etc.).

- Nitrogen compounds include $\mathrm{NO}$ (nitrogen oxide), $\mathrm{NO}_{2}$ (nitrogen dioxide) usually summed up as $\mathrm{NOx}$ (nitrogen oxides) and $\mathrm{N}_{2} \mathrm{O}$ (nitrous oxide). While $\mathrm{NO}$, formation and emissions have been widely investigated for many years, emissions of $\mathrm{N}_{2} \mathrm{O}$ have been in focus in the last years, due to its contribution to the greenhouse effect. Formation of NOx in combustion systems involves three main paths:

- Formation of thermal NOx, which requires sufficiently high temperatures for dissociation of the atmospheric diatomic species $\mathrm{N}_{2}$ and $\mathrm{O}_{2}$;

- Formation of fuel NOx, originating in the fuel bound N;

- Formation of prompt NOx, involving fuel-bound hydrocarbon radicals and atmospheric $\mathrm{N}_{2}$, forming $\mathrm{HCN}$ as the most important intermediate species. 
Nitrogen oxides emissions from small-scale waste biomass regular and fluidized bed cofiring originate mainly from the fuel bound nitrogen, thermal NOx emissions are less important.

However, some discussions on the role of thermal NOx, as well as prompt NOx, have been noticed in the literature regarding the contribution in fluidized bed systems, due to incomplete mixing giving possibilities of fuel rich zones and high temperature zones. For large-scale suspension combustion and co-firing, all mechanisms must be considered.

Co-firing was the selected technology of the present research, and one measured experimental emissions of $\mathrm{NO}, \mathrm{NO}_{2}, \mathrm{SO}_{2}$ and $\mathrm{CO}$ from combustion of mixtures of coal and biomass in bubbling fluidized bed, in order to complete the information with peculiar aspects regarding Romanian bio-fuels and fuel.

At the resource part of biomass supply chain, the following area will have key importance in relation to increase the availability of bio-energy resources (Center for Promotion of Clean and Efficient Energy in Romania [ENERO], 2009):

- Increased crop yields, plant breeding, introduction of new energy crops - this trend is a result of improved land management, improvement of conventional and introduction of new plant breeding techniques, selection of improved varieties and hybrids, increasingly mechanized irrigation, cultivation and harvesting and improved postharvest handling and storage methods, more intensive inputs of fertilizers and agrochemicals. Future land availability for energy crops will depend on the rate of further crop yield improvements. Nutrient recycling and the success and acceptance of genetically modified species will also have an impact on land use and crop yield, as will future water availability, its use and the impacts of climate change.

- Improved harvesting, logistics and pre-treatment of biomass including biochemical conversion process - reduction of supply chain costs could significantly improve economy of bio-energy projects. Larger plants can benefit from economies of scale, but this advantage could be offset by increased transport distances needed to obtain the required volume of biomass. Most often, both small and large scale biomass supply solutions need new types of machinery, new logistics and a new management approach in order to be economical. The improved pre-treatment processes include physical, chemical and biological (enzymatic and other) pre-treatment and conversion processes, biomass fractionation and separation technologies, utilization of residual solids and liquids etc.

\section{Experimental results}

The co-firing tests have been achieved at a ratio of $15-30 \%$ by mass of biomass, the rest being coal.

The temperatures and pressures have been recorded during tests with a data acquisition system, on line, in several important points. All values were in the range of expected relevance: in the furnace $800-1200{ }^{\circ} \mathrm{C}$, in the convective part $300-1200{ }^{\circ} \mathrm{C}$, in the cyclone $150-$ $300{ }^{\circ} \mathrm{C}$, in the scrubber $90-150{ }^{\circ} \mathrm{C}$, and in the neutralization reactor 70-90 ${ }^{\circ} \mathrm{C}$. Figure 6 and 7 shows the temperature variation in furnace and along flue gases path when co-firing $15 \%$ by mass corncob with $85 \%$ pit coal and respectively for co-firing $30 \%$ by mass corncob with $85 \%$ pit coal.

Flue gas composition was measured with Testo 350XL gas analyzers mounted after the cyclone; combined measurement uncertainty for Testo 350XL gas analyzer is $1.19 \%$ 
according to SR EN 50379-1:2004 standard. For dust concentration a Strohlein STE4 device was mounted before cyclone; combined measurement uncertainty for Strohlein STE4 particulate sampling train is $0.03 \%$ according to SR EN 9096:2003 standard.

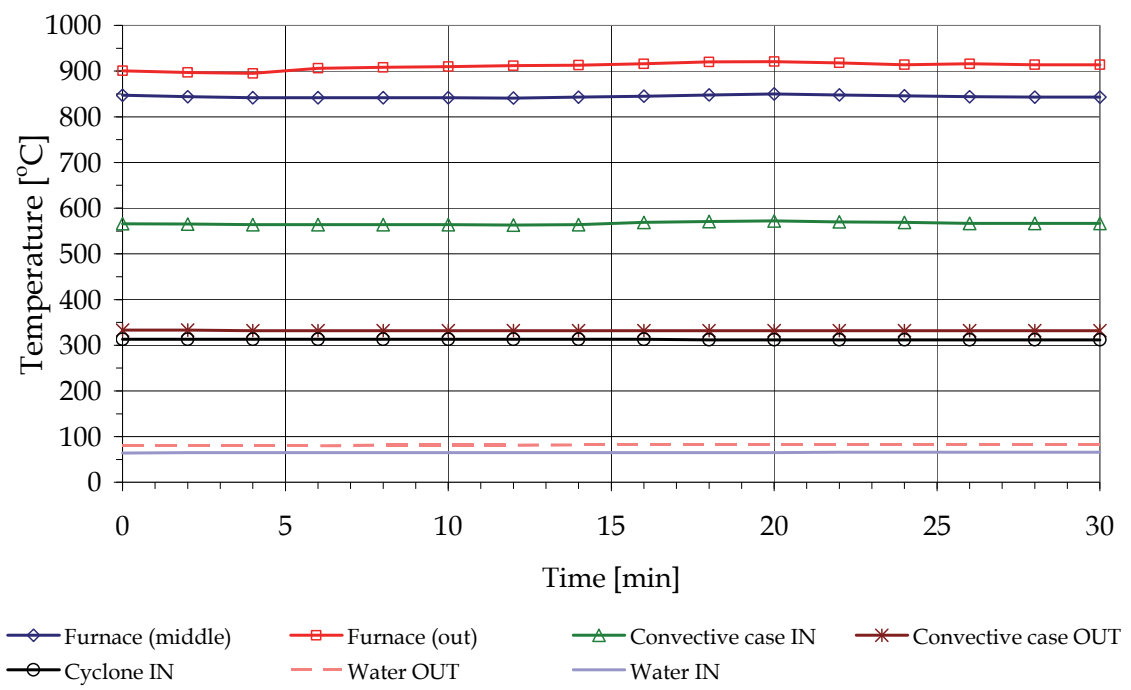

Fig. 6. Temperature variation in furnace and along flue gases path when co-firing $15 \%$ corncob with $85 \%$ pit coal mixture (\% by mass)

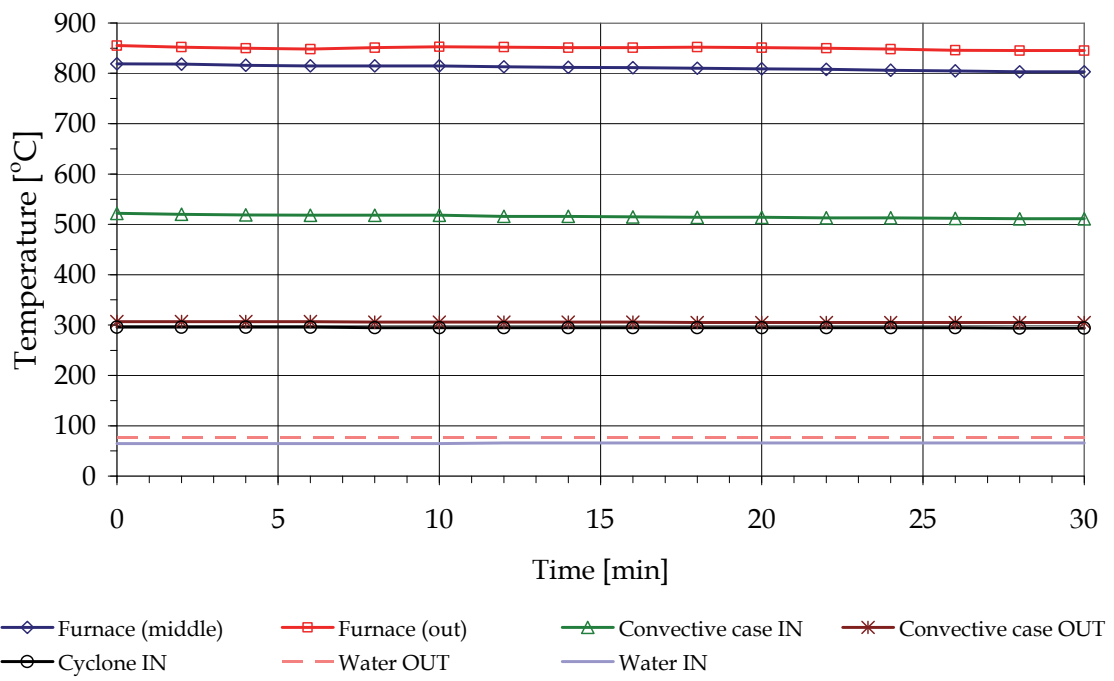

Fig. 7. Temperature variation in furnace and along flue gases path when co-firing $30 \%$ corncob with $70 \%$ pit coal mixture (\% by mass) 
Main results representing average values obtained after achieving a steady state, in several points along the flue gases lay out, are given in Figures 8 - 12. The pit coal ( $\mathrm{Pc}$ ) and lignite (L) co-firing ratio with sawdust (Sd), corncob (Cc) are indicated. For basic comparison, the experiment with no biomass addition was used. Thus, as reference value, one considered the concentration of a species in stack without the biomass mixture. All figures were experimentally determined after the application of the proposed co-firing process.

The results regarding $\mathrm{NO}_{x}$ emissions from co-firing are comparable to those resulting from burning coal alone, as unique fuel. Nitrogen content of biomass is lower comparative to coal, fact that supposes to reduce the formation of $\mathrm{NO}_{\mathrm{x}}$. Nevertheless, the formation of thermal or proximate $\mathrm{NO}_{\mathrm{x}}$ is directly related to the operation techniques, as well, mainly the range of temperature levels covered and oxygen content in reaction zones. Thus one may conclude, that the $\mathrm{N}$ from the biomass and also the thermal mechanism of the $\mathrm{NO}_{\mathrm{x}}$ formation are not activated as expected, due to the fluidized system combustion that limits the temperature levels, and influences the residence time and the oxygen content, as well.

The higher the biomass support, the less $\mathrm{SO}_{2}$ concentration in the flue gases is resulting. The explanation consists of the reduced $S$ content of the used biomass sorts. The achieved desulphurization efficiency accomplished only by the biomass addition (sawdust and respectively corncob), is between 15 and $31 \%$, compared to the reference, when no biomass was added.

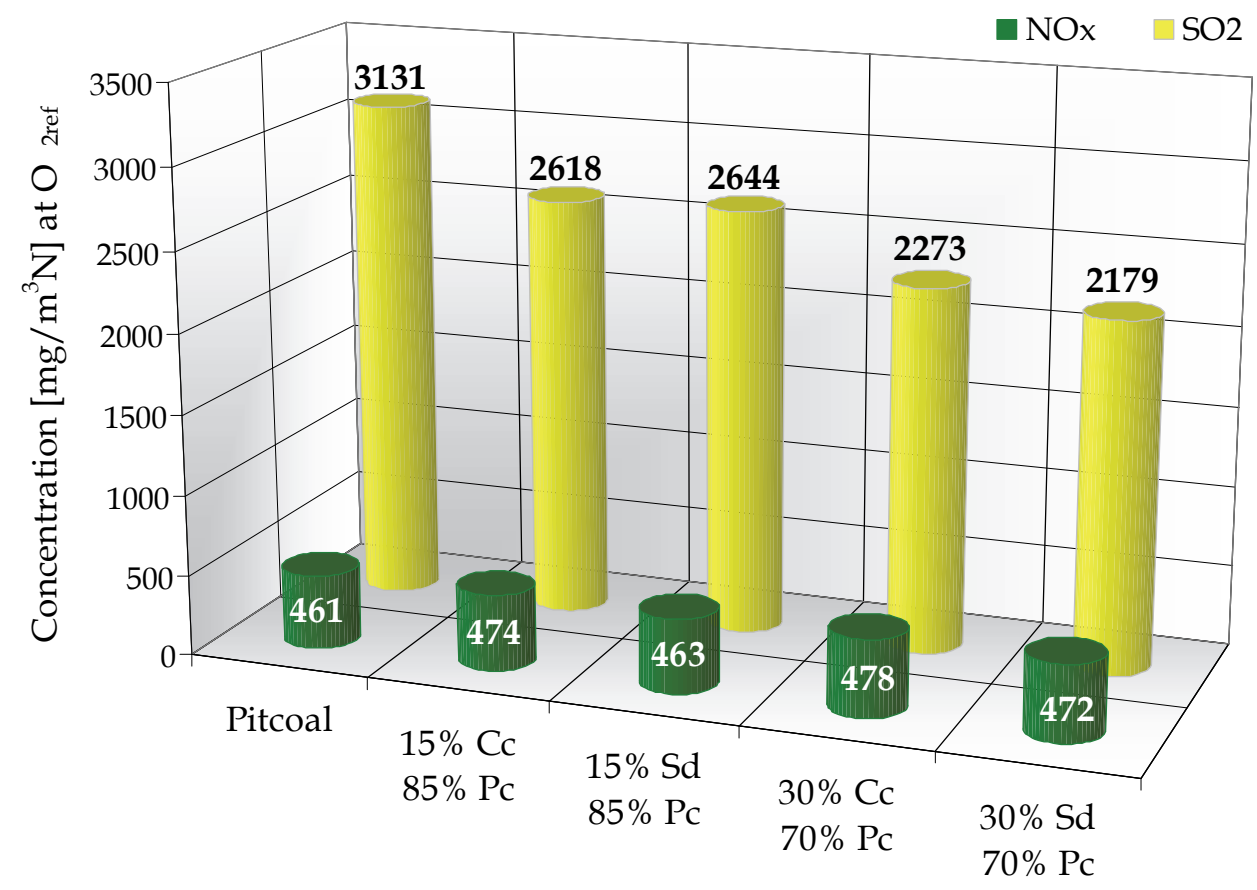

Fig. 8. Average concentration of $\mathrm{SO}_{2}$ and $\mathrm{NO}_{x}$ in the case of pit coal - biomass co-firing, at different mass participation of biomass in the mixture (\% by mass); combined measurement uncertainty is $1.19 \%$ 


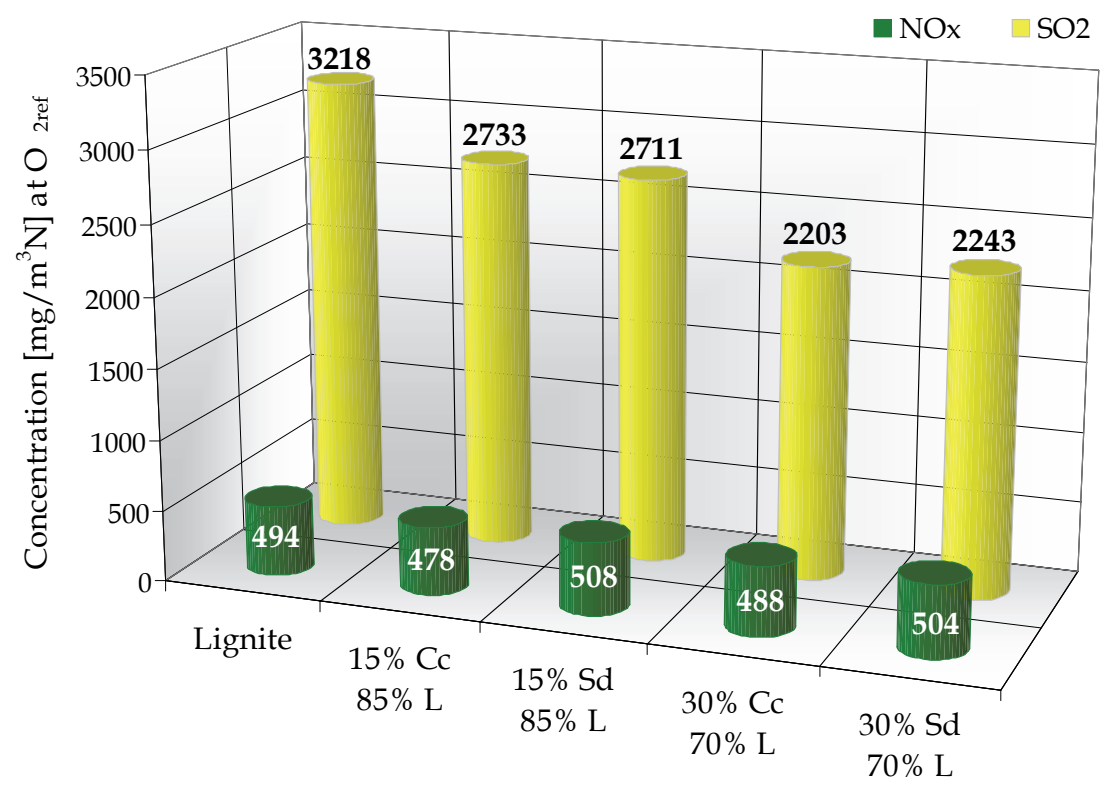

Fig. 9. Average concentration of $\mathrm{SO}_{2}$ and $\mathrm{NO}_{x}$ in the case of lignite - biomass co-firing, at different mass participation of biomass in the mixture ( $\%$ by mass); combined measurement uncertainty is $1.19 \%$

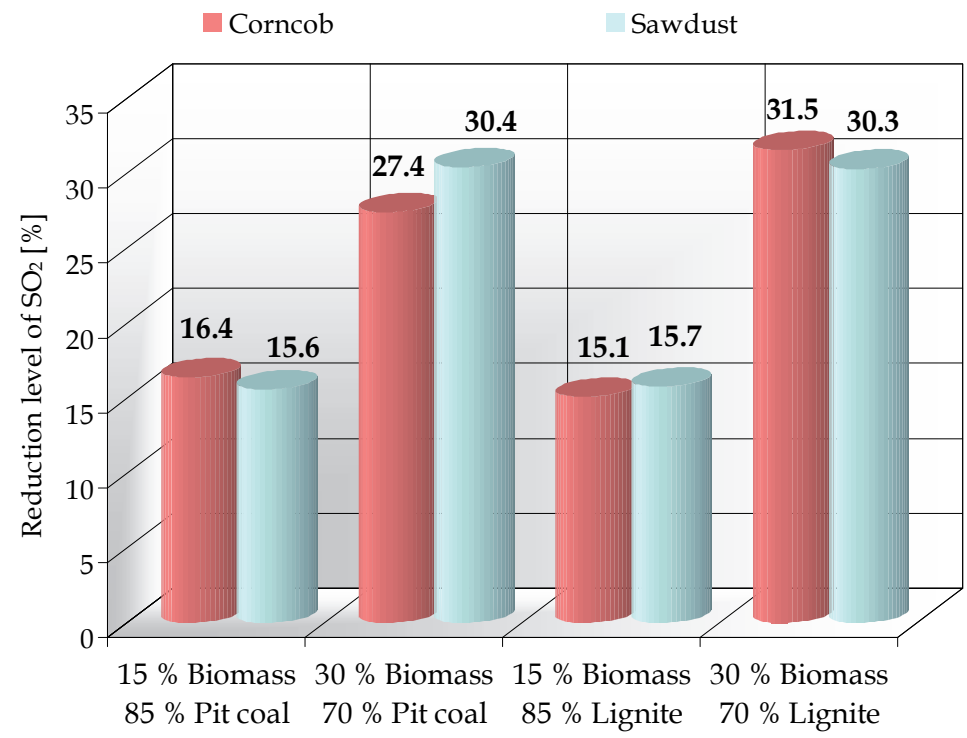

Fig. 10. Desulphurization rate resulted from tests with biomass - coal co-firing (participation of biomass in the mixture is by mass) 
Analyzing the particle concentration in the exhaust flue gases, one notes that the co-firing determines a reduction of the particles amount, explicable by the better combustion conditions, due to the higher volatile content of the biomass, which supports the stability of the ignition and combustion process. With the increasing of biomass mixture ratio, the particles in the flue gases are reduced.

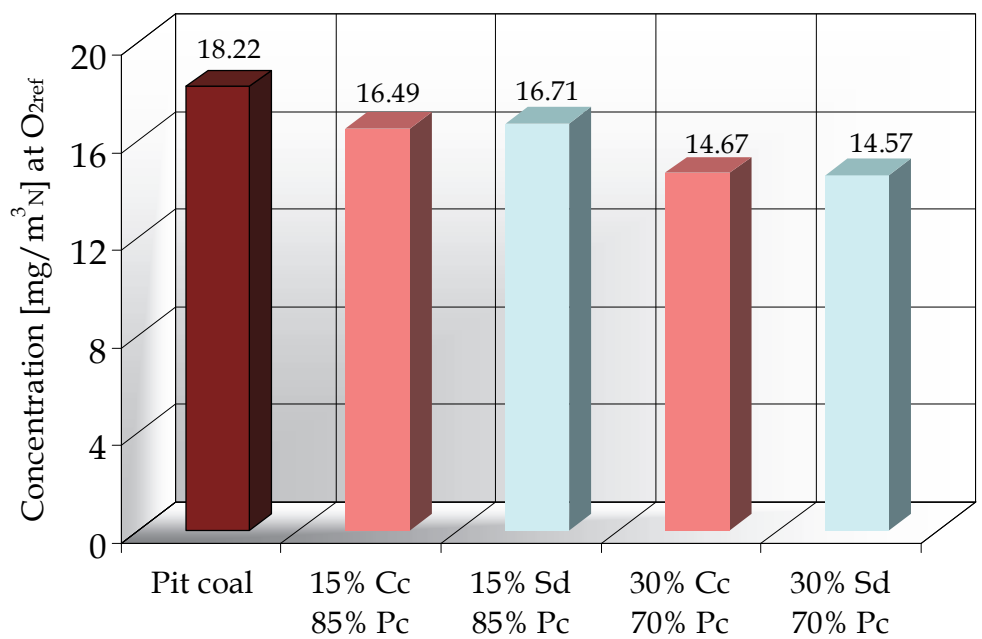

Fig. 11. Mass concentration of dust in the flue gases resulted from co-firing of corncob, respectively sawdust, with pit coal (\% by mass); combined measurement uncertainty is $0.03 \%$

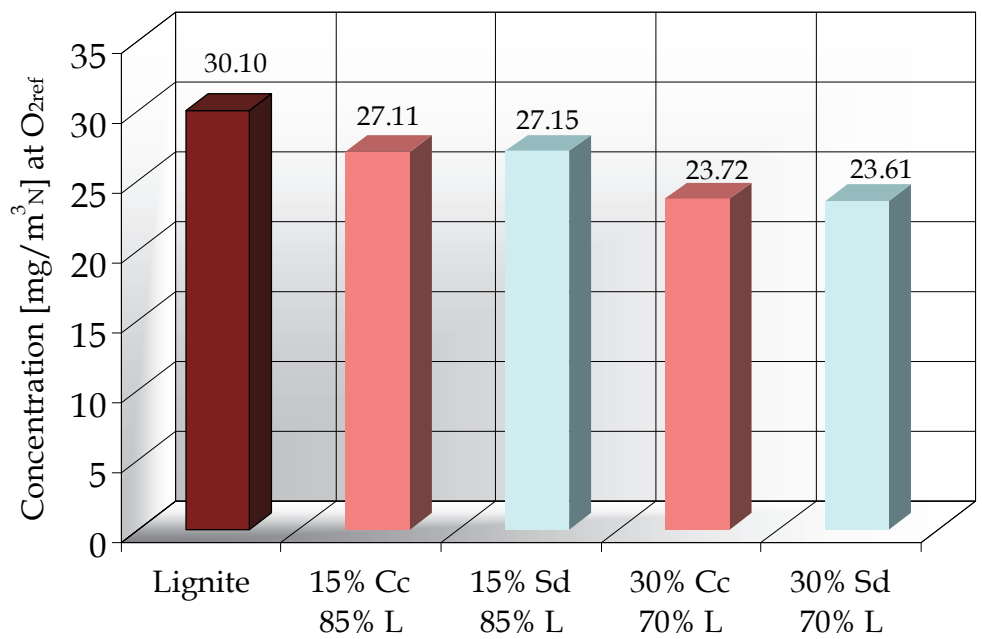

Fig. 12. Mass concentration of dust in the flue gases resulted from co-firing of corncob, respectively sawdust, with lignite (\% by mass); combined measurement uncertainty is $0.03 \%$ 
Figures 13-20 review the stability of the process, as the measured values are quite constant and the variations are negligible, versus a mean value. Increasing the share of biomass (from 15 to $30 \%$ by mass) was found to lead to lower concentrations of $\mathrm{SO}_{2}, \mathrm{NO}$ and $\mathrm{NO}_{2}$ at the bed exit except CO. This is considered to be due to introduction of higher volatile matter with increasing biomass share.

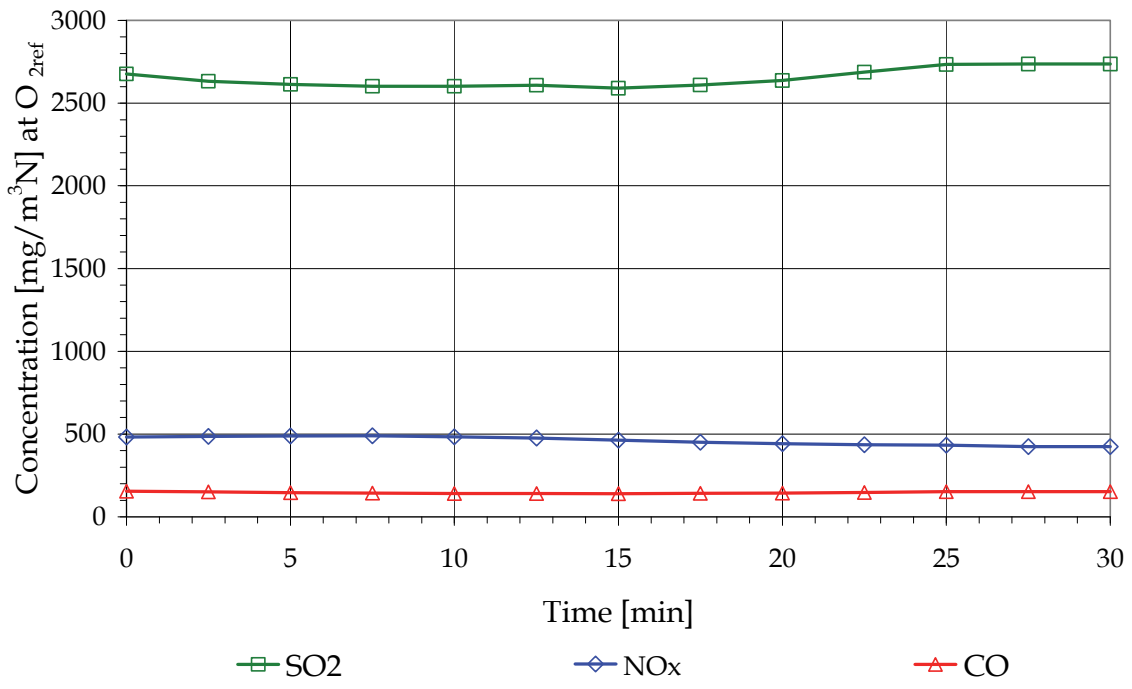

Fig. 13. Time dependence of $\mathrm{SO}_{2}, \mathrm{NO}_{x}$ and $\mathrm{CO}$ concentration when co-firing $15 \%$ by mass sawdust with pit $85 \%$ coal mixture

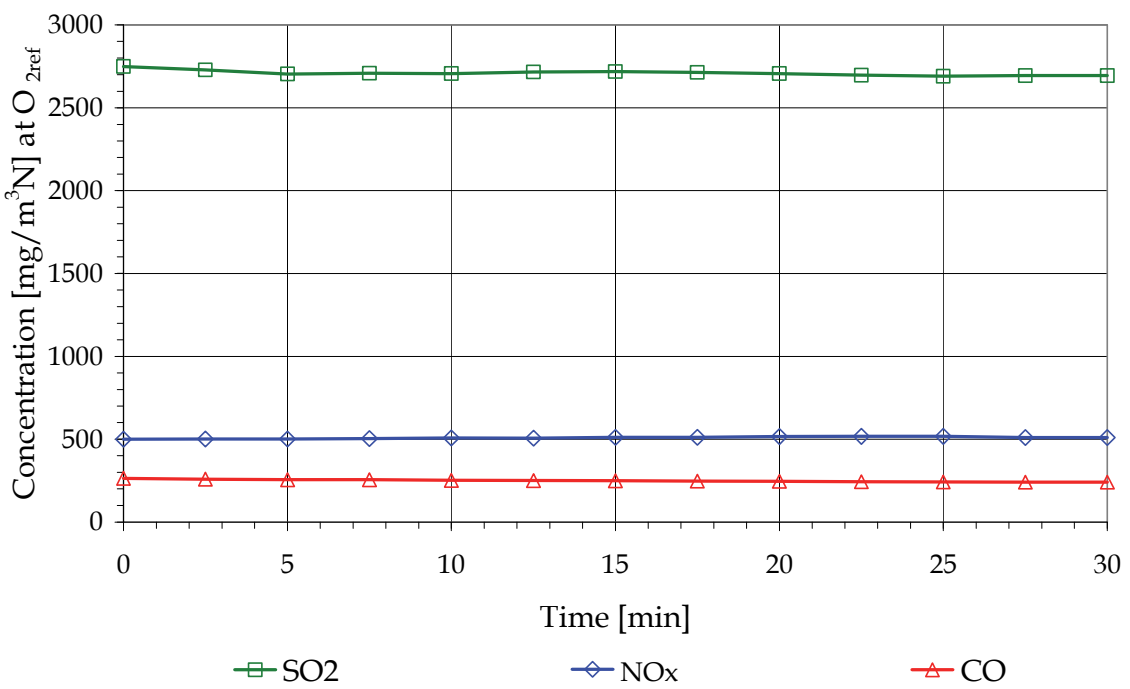

Fig. 14. Time dependence of $\mathrm{SO}_{2}, \mathrm{NOx}$ and $\mathrm{CO}$ concentration when co-firing $15 \%$ by mass sawdust with $85 \%$ lignite mixture 


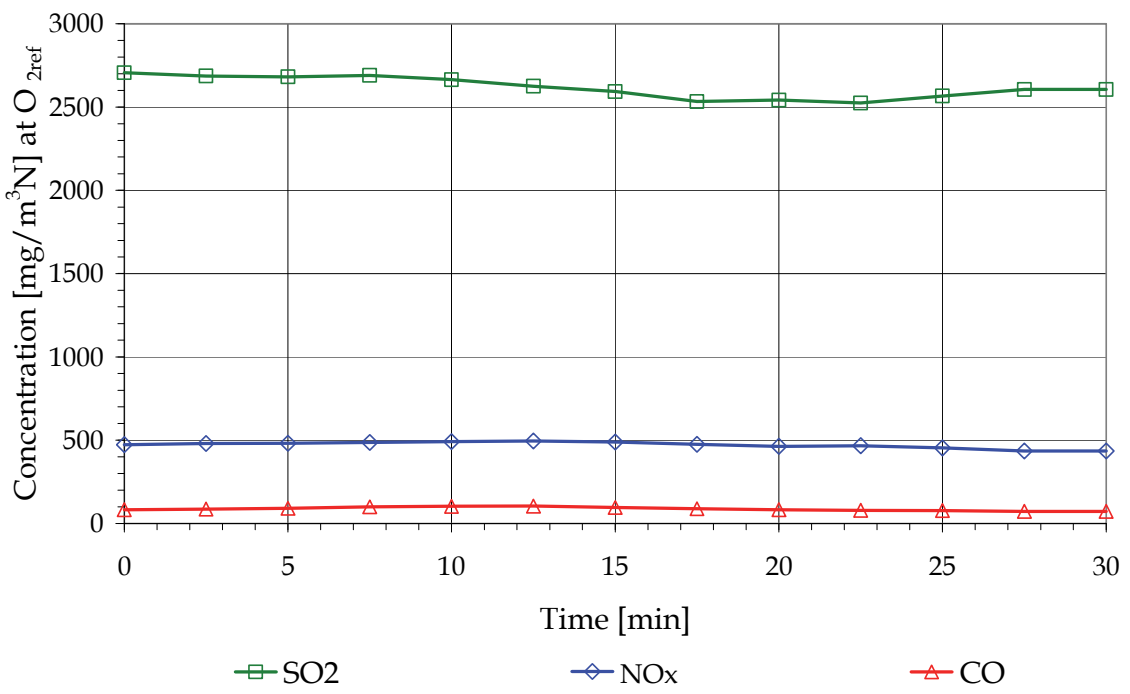

Fig. 15. Time dependence of $\mathrm{SO}_{2}, \mathrm{NO}_{x}$ and $\mathrm{CO}$ concentration when co-firing $15 \%$ by mass corncob with $85 \%$ pit coal mixture

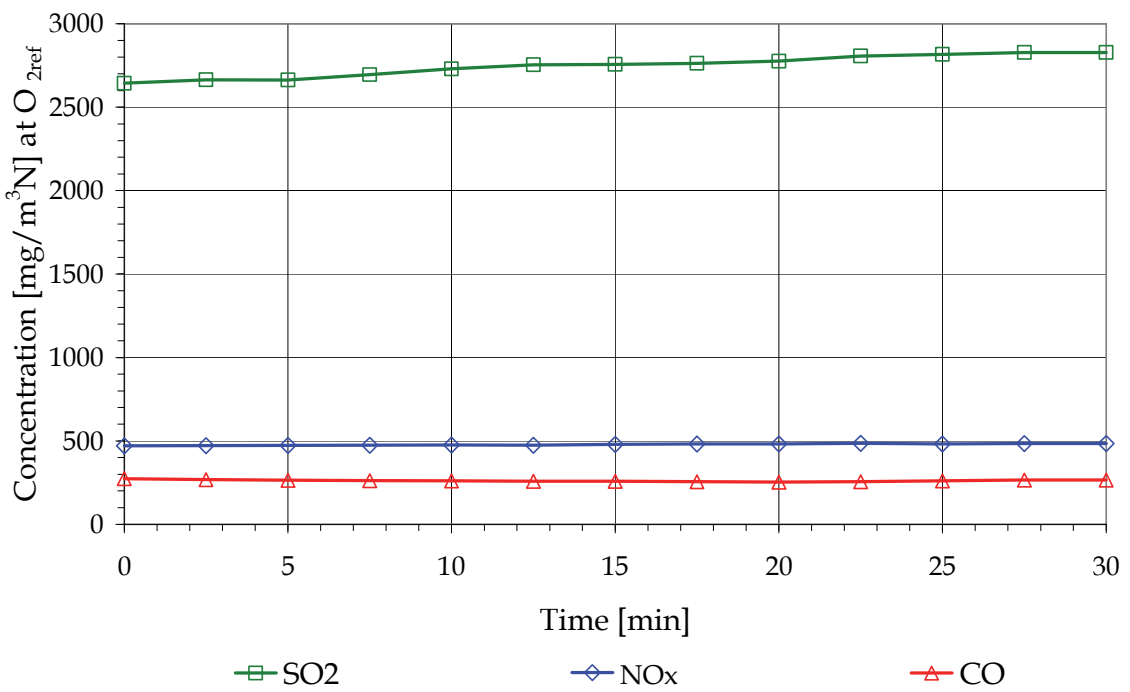

Fig. 16. Time dependence of the $\mathrm{SO}_{2}, \mathrm{NO}_{x}$ and $\mathrm{CO}$ concentration when co-firing $15 \%$ by mass corncob with $85 \%$ lignite mixture

The measured $\mathrm{NO}_{x}, \mathrm{SO}_{2}$ and $\mathrm{CO}$ concentrations at stack are considered reasonable constant. Concerning the unburned $\mathrm{C}(\mathrm{CO})$, the amounts are considerable (between 100 and 350 $\mathrm{mg} / \mathrm{m}^{3} \mathrm{~N}$ at $\mathrm{O}_{2}$ reference) and thus, the efficiency due to unburnt matter of the global cofiring process is reduced, in comparison to the basic case (only coal). This phenomenon suggests that the biomass addition can enhance the ignition of coal, since volatile matter in 
biomass is easily evolved even at relatively low temperature, and because lack of oxygen, the $\mathrm{CO}$ is generated more intensively as if no biomass is added.

In general, when the volatile matter content is low the reactivity is low too and the combustion of this fuel is more difficult. The coal has, in some cases, a lower reactivity or comparative, in other, even higher than the biomass species. The presence of unburned particles in the ash is higher or less, resulting, in majority of cases, a decrease of the combustion efficiency. The high reactivity of the biomass species compared to that of coal char, results in a rapid burnout of the biomass particles in case such particles would have survived the passage through the combustion chamber to burn in the cyclone together with the combustible gases.

If the share of biomass is less than $5 \%$ by mass, it was been demonstrated that there are no relevant CO increased values in the flue gases (Van Loo \& Koppejan, 2007).

The advantage of the co-firing is for sure the benefit concerning the $\mathrm{CO}_{2}$ emission, knowing that the $\mathrm{CO}_{2}$ exhaust from fossil fuel origin is reduced by the same amount as the biomass ratio. Despite the fact that normally not the total $\mathrm{CO}_{2}$ resulted from the biomass share might be considered green, neutral, as according to the lack of relevant differences - in terms of experimental results - concerning the two used biomass qualities and ratio attest the fact that fuel flexibility is possible. Varying qualities and quantities of fuels can be partially compensated by adjusting the co-firing rate.

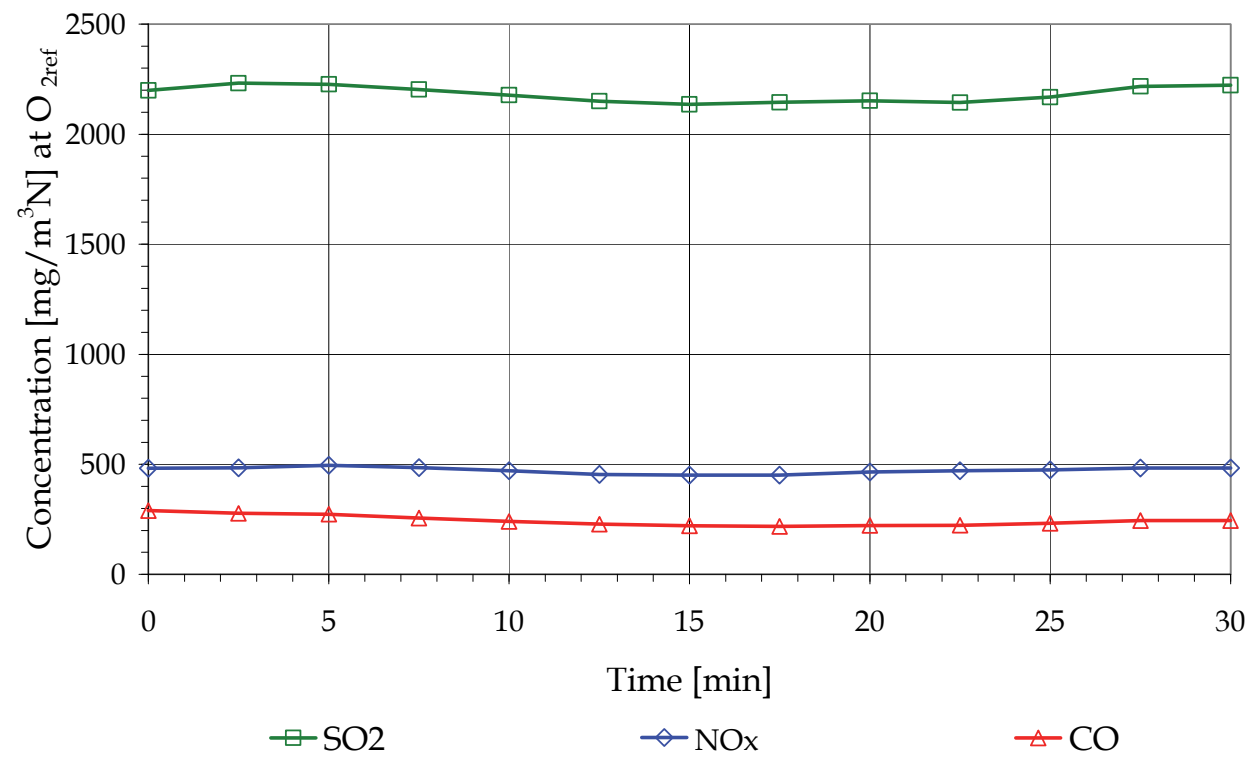

Fig. 17. Time dependence of $\mathrm{SO}_{2}, \mathrm{NO}_{x}$ and $\mathrm{CO}$ concentration when co-firing $30 \%$ by mass sawdust with $70 \%$ pit coal mixture 


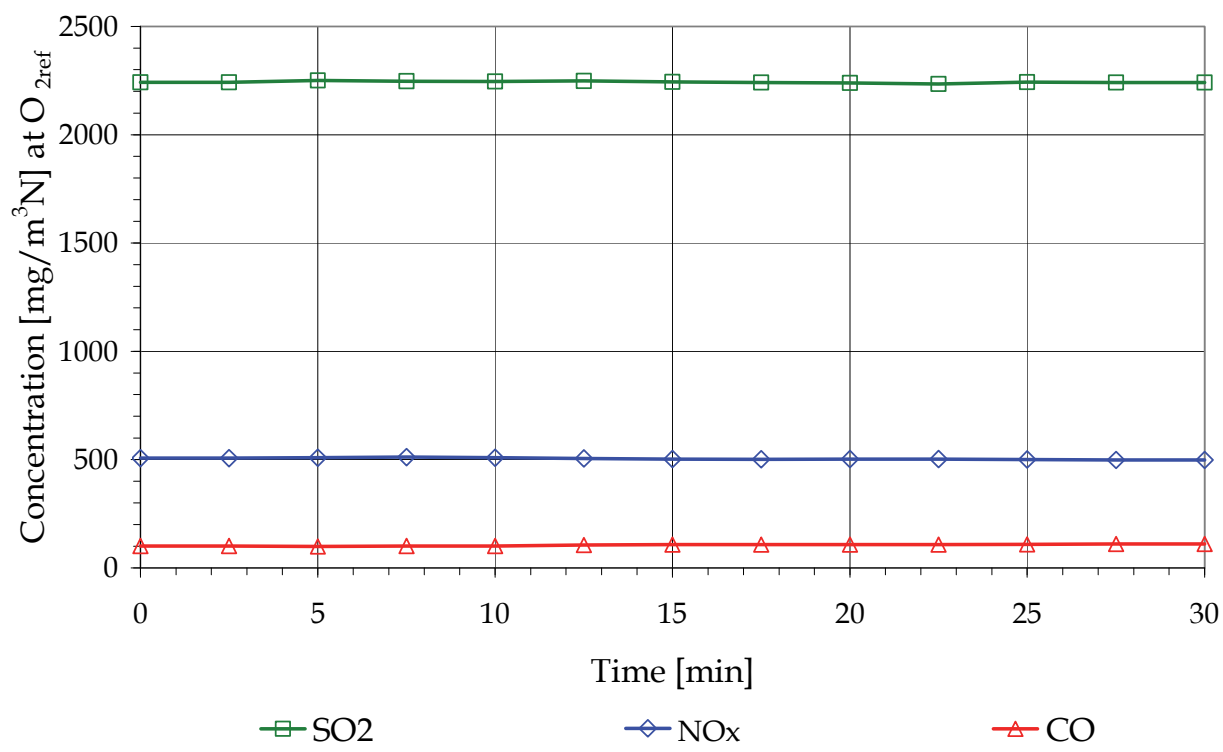

Fig. 18. Time dependence of $\mathrm{SO}_{2}, \mathrm{NO}_{x}$ and $\mathrm{CO}$ concentration when co-firing $30 \%$ by mass sawdust with $70 \%$ lignite mixture

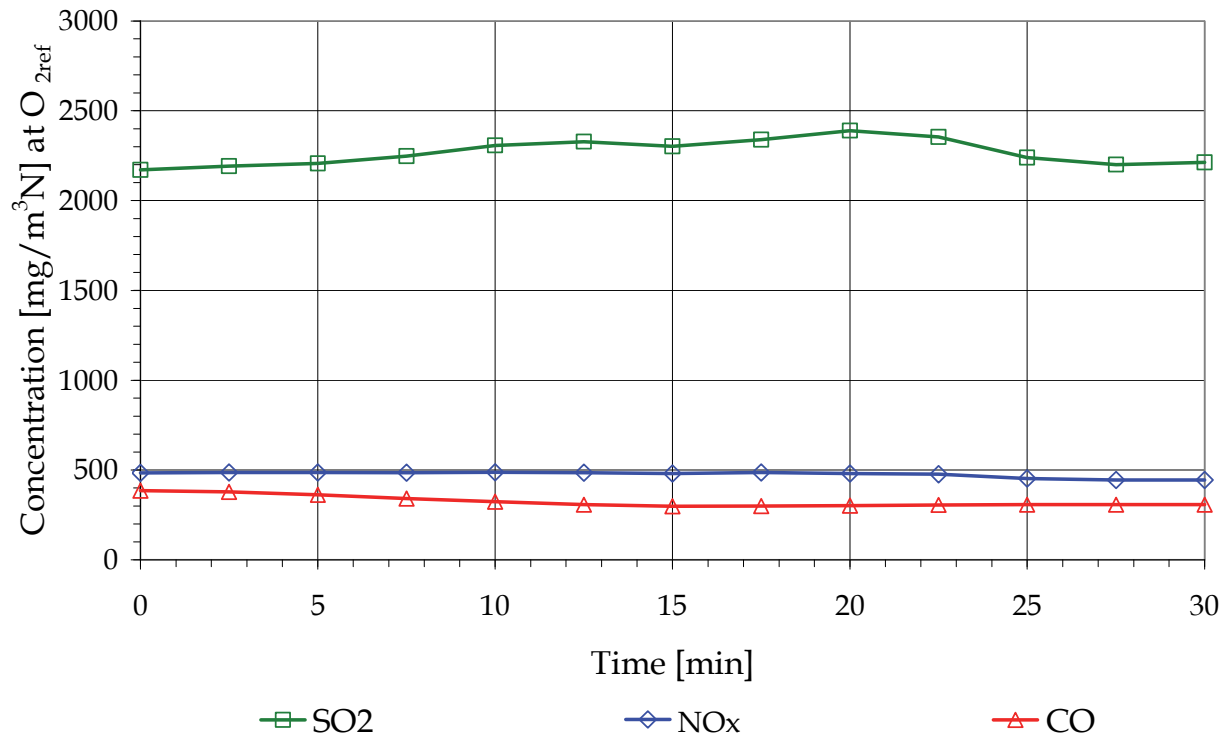

Fig. 19. Time dependence of the $\mathrm{SO}_{2}, \mathrm{NOx}$ and $\mathrm{CO}$ concentration when co-firing $30 \%$ by mass corncob with $70 \%$ pit coal mixture 


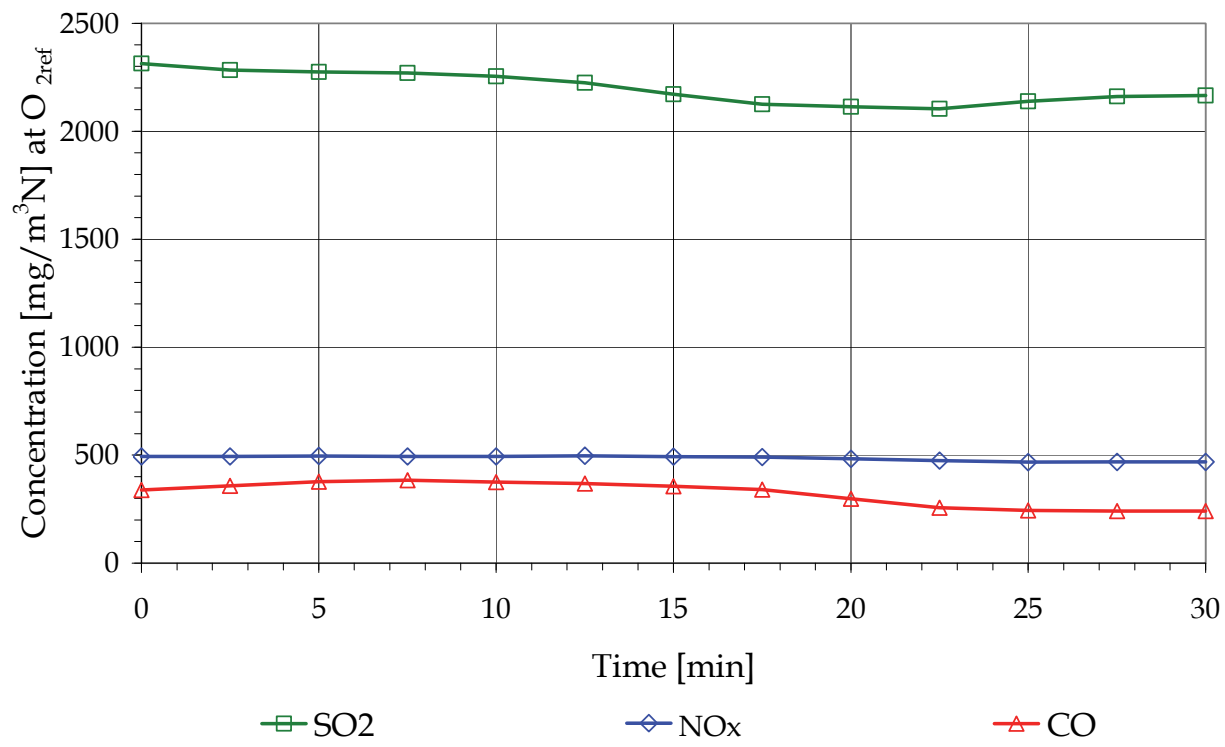

Fig. 20. Time dependence of the $\mathrm{SO}_{2}$, NOx and $\mathrm{CO}$ concentration when co-firing $30 \%$ by mass corncob with $70 \%$ lignite mixture

\section{Conclusions}

As specific comparative result, one indicates that between the two test series accomplished on co-firing of biomass species (sawdust and corncob) in addition to coal no major relevant differences resulted, despite the difference of heat value, determining higher temperatures, with all resulting benefits and disadvantages. Both species of waste biomass are appropriate to be used in co-firing with coal, in slightly retrofitted existing facilities, normally used for one fuel. The support of other fossil fuel is not needed. In order to improve the efficiency of the co-firing process, one suggests to continue the tests for reducing the unburned carbon (CO) values in the flue gases, that is the main reason for a lower thermal efficiency of the process, in comparison to the classic (fossil fuel) case. Also the $\mathrm{CO}$ amount is over the limits permitted for a clean combustion and stack concentration.

Important relevant experimental conclusions, compared to the unblended combustion tests, are noticed:

- The fuel cost under the co-firing circumstances is, under the specific conditions from Romania, lower as in comparison to alone fossil fuel utilization;

- Reduction of the $\mathrm{SO}_{2}$ concentration in the flue gases occurs, in accordance to the biomass ratio; there are theories that the composition of the biomass might act also in influencing this process, as well;

- Using fluidized bed technology, not notable NOx enhanced emissions in case of the cofiring was attested, due to the higher heating value of the biomass in comparison to the coal.

- No special deposit problems have been recorded; one reason might be the special outfit of the furnace, according to the design of the fluidized bed combustor. 
- A reduction of the thermal efficiency (due to a higher unburned $C$ in the flue gases) is caused by the presence of biomass in the blended fuel;

- The particle concentration in the flue gases is reduced in the case of the co-firing, in accordance to the biomass content, the explanation being also connected to the reduced ash content in biomass;

- In order to generate a total $\mathrm{CO}_{2}$ lean global process, one suggests adding finally, a technology of capturing the $\mathrm{CO}_{2}$ by absorption (through scrubbing with monomethanol-amine MEA). The $\mathrm{CO}_{2}$ emission might be also reduced and controlled by paying the price for the supplementary technology.

As further plans one will study the corrosion aspects, knowing that they are related to alkali metals and chlorine and might turn into a major problem. In addition, the utilization of the residues (ash) is term of further and peculiar analysis and research.

The experimental results demonstrate that the co-firing technology, for Romania, represents a progress, and is worth to be applied in industrial environment also, taking into consideration the potential of local biomass availability. The technology is stable, is expected to be applied with a large share of waste biomass, and by applying flue gas cleaning technologies, the limits for the pollutants' concentration in stack might be respected.

When proper choices of biomass, coal, boiler design, and boiler operation are made, traditional pollutants $\left(\mathrm{SO}_{x}, \mathrm{NO}_{x}\right.$, etc.) and net greenhouse gas $\left(\mathrm{CO}_{2}, \mathrm{CH}_{4}\right.$, etc.) emissions decrease. Ancillary benefits include a reduced dependency on imported fuels and decreased demand for disposal of residues. These advantages can be realized in the very near future with relatively low technical risks. Therefore, commercialization of co-firing technologies offers among the best short- and long-term solution to greenhouse gas emissions from power generation. Since co-firing is not an option in all areas, a robust biomass utilization strategy requires development of alternative technologies as well. The effectiveness of the co-firing option, combined with its low cost and low technical risk, should place it high on a priority list of institutions considering an array of greenhouse gas options (Baxter \& Koppejan, 2005). However, there are many issues that, if not carefully managed, could compromise the boiler or downstream processes. Results to date indicate that these are all manageable but they require careful consideration of fuels, boiler operating conditions, and boiler design.

It is anticipated that the biomass co-firing activities in Europe will continue to expand over the next few years. It is clear, however, that the limits to the expansion of co-firing will depend on the attitude of the specific governments and the limitations applied to the eligibility of co-firing under the Renewable Obligation Order. At present, co-firing is perceived by some governments as a relatively short-term approach to the production of electricity from renewable sources, which will help to create a biomass fuel supply infrastructure, and in particular will help to develop the cultivation and supply of indigenous energy crop materials. In a broader context, and taking a longer term view, cofiring clearly provides the most efficient and lowest risk means for generating electricity from biomass, which in Europe, at least, is a relatively scarce and expensive energy source. In those countries where utilization of coal will continue to play a significant role in the fuel mix for power generation, co-firing has a key role to play in the meeting the challenges represented by global warming, and the imperative to develop means of progressively reducing fossil fuel utilization (Livingston, 2005).

The results of this paper confirm that biomass is the only renewable energy source that can replace fossil fuels directly. By blending solid biomass fuels with corresponding fossil fuels 
different applications (from small scale to large scale) are possible. Thus co-utilization of biomass fuels with fossil fuels is a quick and relatively reliable way to reduce greenhouse gas emissions and preserve natural resources. It is therefore a sustainable, interim mechanism for meeting commitments to the Kyoto Protocol.

Co-firing of solid biomass with fossil fuels (mainly coal) represents an attractive option for the large-scale power plant's infrastructure and high electrical conversion efficiency. The technology is available and is based on many different types of biomass. Compared to most other forms of bio-energy, co-utilization of biomass in modern, highly efficient CHP (combined heat and power) and power plants is commercially available, represent technically, and environmentally an attractive solution for all countries that aim to increase the proportion of renewable electricity in the general energy balance. However, as all other renewable energy sources, this too is dependent on policy instruments.

Secure supply and an offer of mixture in the potential biomass share, also including short rotation coppices are main requirements for further implementation, especially under the conditions, where lack of organization in biomass flow is attested, despite best climate and soil conditions exist. Combustion of solid fossil fuel with biomass should represent both a retrofit option, but also a very good solution from the start of the project. The bio-energy creates jobs and secures energetically the region/country, being also an alternative for developing local skills, and economic growth.

\section{References}

Baxter, L. \& Koppejan, J. (2005). Biomass-coal co-combustion: opportunity for affordable renewable energy, Fuel, Vol. 84, Issue 10, July 2005, pp. 1295-1302, ISSN: 0016-2361

Center for Promotion of Clean and Efficient Energy in Romania (2009). Market development Biomass Romania. Survey: Current status \& possibilities market chains, Ref. no. BIORM 08002, Developed by ENERO Romania, September 2009, Bucharest

European Commission (2005). EUR 21350 - Biomass - Green energy for Europe, Office for Official Publications of the European Communities, ISBN 92-894-8466-7, Luxembourg

European Commission (2003). Biomass co-firing - an efficient way to reduce greenhouse gas emission, European Bioenergy Networks, ALTENER programme and the Finnish Ministry of Trade and Industry, Finland

Ghergheleş, V. (2006). Future energy, renewable sources, Mediamira publishing house, ISBN 973-713-146-0, Cluj-Napoca

Hansson, J.; Berndes, G.; Johnsson, F. \& Kjärstad, J. (2009). Co-firing biomass with coal for electricity generation - An assessment of the potential in EU 27. Energy Policy, Vol. 37, Issue 4, April 2009, pp. 1444-1455, ISSN: 0301-4215

Ionel, I.; Popescu, Fr.; Lontis, N.; Trif-Tordai, G. \& Russ W. (2009). Co-combustion of fossil fuel with bio-fuel in small cogeneration systems between necessity and achievements, Proceeding of 11th WSEAS International Conference on Sustainability in Science Engineering, ISBN 978-960-474-080-2, Timisoara, Romania, 27-29 May 2009

Ionel, I.; Ungureanu, C.; Trif-Tordai, G.; Tenchea, A.; Silaghi, Diana. \& Constantin, C. (2007). Management of biomass energy recovery, "Politehnica" publishing house Timisoara, ISBN 978-973-625-541-0, Timisoara 
Livingston, W. R. (2005). A review of the recent experience in Britain with the co-firing of biomass with coal in large pulverized coal-fired boilers, IEA ExCo55 Workshop on Biomass Co-firing, Copenhagen, Denmark, 25 May 2005

Romanian patent no. 121362/30.07.2007 (2007). Procedure and facility for the combined combustion of agricultural or municipal waste with coal and flue gas cleaning technologies, Owners: SC SAVPROD SA \& "Politehnica" University of Timisoara

Romanian Ministry of Environment and Forests (2007). www.mmediu.ro, Romania

Trif-Tordai G. (2008). Researches on biomass with coal co-firing-PhD Thesis, "Politehnica" publishing house Timisoara, ISBN 978-973-625-713-1, Timisoara

T,ânțăreanu, C. (2009). Biomass potential in Romania. The CEUBIOM project approach. In: ENERO-Centre for promotion of clean and efficient energy in Romania, 29 January 2009, Available from www.enero.ro

Van Loo, S. \& Koppejan, J. (2007). The handbook of Biomass Combustion \& Co-firing, Earthscan publishing house, ISBN 978-1-84407-249-1, London 


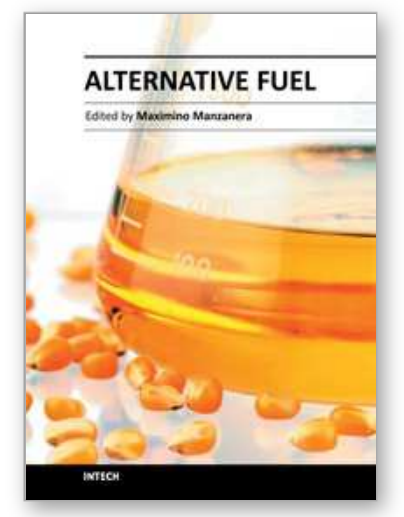

\author{
Alternative Fuel \\ Edited by Dr. Maximino Manzanera
}

ISBN 978-953-307-372-9

Hard cover, 346 pages

Publisher InTech

Published online 09, August, 2011

Published in print edition August, 2011

Renewable energy sources such as biodiesel, bioethanol, biomethane, biomass from wastes or hydrogen are subject of great interest in the current energy scene. These fuels contribute to the reduction of prices and dependence on fossil fuels. In addition, energy sources such as these could partially replace the use of what is considered as the major factor responsible for global warming and the main source of local environmental pollution. For these reasons they are known as alternative fuels. There is an urgent need to find and optimise the use of alternative fuels to provide a net energy gain, to be economically competitive and to be producible in large quantities without compromising food resources.

\title{
How to reference
}

In order to correctly reference this scholarly work, feel free to copy and paste the following:

Gavrilă Trif-Tordai and loana lonel (2011). Waste Biomass as Alternative Bio-Fuel - Co-Firing versus Direct Combustion, Alternative Fuel, Dr. Maximino Manzanera (Ed.), ISBN: 978-953-307-372-9, InTech, Available from: http://www.intechopen.com/books/alternative-fuel/waste-biomass-as-alternative-bio-fuel-co-firing-versusdirect-combustion

\section{INTECH}

open science | open minds

\section{InTech Europe}

University Campus STeP Ri Slavka Krautzeka 83/A 51000 Rijeka, Croatia Phone: +385 (51) 770447

Fax: +385 (51) 686166 www.intechopen.com

\section{InTech China}

Unit 405, Office Block, Hotel Equatorial Shanghai No.65, Yan An Road (West), Shanghai, 200040, China 中国上海市延安西路65号上海国际贵都大饭店办公楼405单元 Phone: +86-21-62489820

Fax: +86-21-62489821 
(C) 2011 The Author(s). Licensee IntechOpen. This chapter is distributed under the terms of the Creative Commons Attribution-NonCommercialShareAlike-3.0 License, which permits use, distribution and reproduction for non-commercial purposes, provided the original is properly cited and derivative works building on this content are distributed under the same license. 